\title{
Pengaruh model pembelajaran berbasis masalah terhadap kemampuan berpikir logis matematis siswa pada materi program linier
}

\author{
Prangga Assmarqandi ${ }^{*}$, Laila Hayati ${ }^{2}$, Hapipi ${ }^{2}$ \\ ${ }^{1}$ Mahasiswa Pendidikan Matematika, FKIP, Universitas Mataram, Mataram \\ 2 Pendidikan Matematika, FKIP, Universitas Mataram, Mataram \\ pranggaassmarqandi@gmail.com
}

Diterima: 11 Juni 2021; Direvisi: 26 Juni 2021; Dipublikasi: 30 Juni 2021

\begin{abstract}
This research aims to determine the effect of problem-based learning model on student's mathematical logical thinking abilities and the amount of it. To achieve the goals, this research used post-test only control group design. This research was held in class XI-IPA of SMAN 1 Sekotong and consist of 60 students which divided into two classes. By considering the post-test only control group design which requires a control group and the experimental group, used saturated sampling technique that took the whole population as the sample. The members of the population were all students of class XI-IPA of SMAN 1 Sekotong which divided into two classes XI-IPA 1 and XI-IPA 2. The instruments were used to measure the student's logical thinking ability consist of four description. The measurement of the logical thinking ability was measured after the implementation of problem-based learning for four times. The level of compliance to the learning model was measured by observation of student and teacher activity sheets. The results of data analysis using t-test showed that problem-based learning have a significant influence on the mathematical logical thinking ability. Those results were showed by the increasing of mathematical logical thinking ability in each meeting. The analysis using the effect-size gave the result of the d value of 1,60 which means the application of problembased learning have a high influence to the student's mathematical logical thinking ability.
\end{abstract}

Keywords: Mathematical Logical Thinking Abilities; Problem Based Learning

\begin{abstract}
Abstrak
Penelitian ini bertujuan untuk mengetahui pengaruh model pembelajaran berbasis masalah terhadap kemampuan berpikir logis matematis siswa dan besar dari pengaruh model pembelajaran tersebut. Dalam mencapai tujuan tersebut, digunakan desain penelitian post-test only control group. Penelitian ini dilakukan di kelas XI-IPA SMAN 1 Sekotong dan melibatkan 60 siswa yang terbagi menjadi dua kelas. Dengan mempertimbangkan desain post-test only control group yang membutuhkan kelompok kontrol dan kelompok eksperimen, digunakanlah teknik sampling jenuh yang mengambil seluruh anggota populasi sebagai sampel. Anggota populasi yang dimaksud adalah seluruh siswa kelas XI-IPA SMAN 1 Sekotong yang terbagi menjadi dua kelas yakni XI-IPA 1 dan XI-IPA 2. Instrumen yang digunakan untuk mengukur kemampuan berpikir logis siswa berbentuk uraian yang terdiri dari empat soal. Pengukuran kemampuan berpikir logis dilakukan setelah dilaksanakannya model pembelajaran berbasis masalah sebanyak empat pertemuan. Tingkat keterlaksanaan model pembelajaran tersebut diukur dengan lembar observasi aktivitas siswa dan guru. Hasil analisis data menggunakan uji-t menunjukkan bahwa model pembelajaran berbasis masalah memberikan pengaruh yang signifikan terhadap kemampuan berpikir logis matematis. Hasil tersebut didukung dengan peningkatan kemampuan berpikir logis matematis pada setiap pertemuan. Analisis menggunakan effect-size menghasilkan nilai d sebesar 1,60 yang berarti penerapan model pembelajaran berbasis masalah memiliki pengaruh yang besar terhadap kemampuan berpikir logis matematis siswa.
\end{abstract}

Kata Kunci: Kemampuan Berpikir Logis Matematis; Pembelajaran Berbasis Masalah 


\section{PENDAHULUAN}

Matematika adalah ilmu tentang keteraturan dan struktur yang terorganisasikan. Konsep-konsep matematika tersusun secara hirarkis, berstruktur dan sistematis, dari konsep yang sederhana hingga kompleks (Hasratuddin, 2014). Konsep yang tersusun sistematis ini bertujuan untuk membekali siswa dengan berbagai kemampuan yang salah satunya adalah kemampuan berpikir logis (As'ari, Abdur, Tohir, \& Valentino, 2017). Hal serupa tertulis pada Permendikbud No.21 tahun 2016 yang mengungkapkan bahwa kompetensi yang diharapkan setelah siswa mempelajari matematika adalah menumbuhkan sikap positif yaitu berpikir logis, kritis, analitis, cermat dan teliti, bertanggung jawab, responsif, dan tidak mudah menyerah (Menteri Pendidikan Dan Kebudayaan, 2016).

Salah satu kemampuan yang mempengaruhi pembelajaran matematika adalah kemampuan berpikir logis. Nursupianah di SMAN 1 Rajagaluh Majalengka mengungkapkan bahwa terdapat hubungan yang signifikan antara pola berpikir logis dengan hasil belajar matematika siswa di sekolah tersebut (Nursupianah \& Fitriyah, 2012). Penelitian yang dilakukan oleh Zulfairnatama menyatakan hasil serupa. Terdapat pengaruh yang signifikan pada kemampuan berpikir logis siswa terhadap prestasi belajar matematika (Zulfairanatama \& Hadi, 2013). Untuk itu, guna meningkatkan prestasi belajar siswa dalam matematika, salah satu upaya yang dapat dilakukan yaitu dengan meningkatkan kemampuan berpikir logis siswa tersebut.

Terdapat masalah dalam pembelajaran matematika di SMAN 1 Sekotong. Masalah tersebut adalah rata-rata nilai yang berada di bawah KKM (75) seperti yang ditunjukkan pada tabel 1.

Tabel 1. Rata-Rata Nilai Ulangan Harian Kelas XI-IPA SMA Negeri 1 Sekotong pada Materi Induksi Matematika Tahun Pelajaran 2019/2020

\begin{tabular}{cc}
\hline Kelas & Rata-rata \\
\hline XI-IPA 1 & 70 \\
XI-IPA 2 & 70,7 \\
\hline
\end{tabular}

Dalam upaya menyelesaikan masalah tersebut, kemampuan berpikir logis siswa perlu ditingkatkan. Kemampuan berpikir logis adalah kemampuan berpikir siswa untuk menarik kesimpulan yang sah berdasarkan aturan logika dan dapat membuktikan bahwa kesimpulan itu benar sesuai dengan pengetahuan-pengetahuan sebelumnya yang telah diketahui (Siswono, 2007). Logika adalah sarana untuk berpikir secara sistematis, valid, dan dapat dipertanggung jawabkan. Oleh karena itu, berpikir logis adalah berpikir sesuai dengan aturan-aturan berpikir yang terdiri dari tiga aspek di atas (Suaedi, 2016).

Model yang terbukti dapat meningkatkan kemampuan tersebut adalah model pembelajaran berbasis masalah (Rohaeti, Budiyanto, \& Sumarmo, 2014). Pembelajaran berbasis masalah (PBM) adalah suatu kegiatan pembelajaran yang berpusat pada masalah. Model pembelajaran berbasis masalah menuntut aktivitas mental siswa dalam 
memahami suatu konsep, prinsip, dan keterampilan melalui situasi atau masalah yang disajikan di awal pembelajaran. Situasi atau masalah menjadi titik tolak pembelajaran untuk memahami prinsip, dan mengembangkan keterampilan yang berbeda (Nurdyansyah, 2016). Dalam PBM, peserta didik sering kali menggunakan bermacammacam keterampilan dan prosedur penyelesaian masalah (Jufri, 2013). Model pembelajaran berbasis masalah adalah pembelajaran yang menitik beratkan kepada proses (Jurkovic, Sarlota, Vukadinovic, \& Jarc, 2005). Dari penjelasan di atas, dapat disimpulkan bahwa PBM adalah model pembelajaran yang menitik beratkan kepada proses dalam menyelesaikan masalah kontekstual dan membutuhkan bermacam-macam keterampilan dan prosedur penyelesaian masalah.

Terdapat beberapa kelebihan yang dimiliki model pembelajaran berbasis masalah diantaranya: (1) Pembelajaran berbasis masalah berpusat kepada siswa, (2) kegiatan siswa difokuskan pada pekerjaan yang serupa dengan situasi yang sebenarnya sehingga menghasilkan sikap profesional, (3) kegiatan dalam PBM sudah sesuai dengan kurikulum, (4) kegiatan diskusi, presentasi, dan evaluasi membuat proses belajar menjadi menyenangkan, (5) materi yang dipelajari dapat digali lebih dalam oleh siswa karena berkaitan dengan kehidupan sehari-hari, (6) siswa membangun sendiri pengetahuannya (Wood, 2003). Berdasarkan kelebihan-kelebihan tersebut, diharapkan penerapan model pembelajaran berbasis masalah dapat meningkatkan kemampuan berpikir logis siswa di SMA Negeri 1 Sekotong.

Berdasarkan penjelasan di atas maka perlu dilakukan penelitian yang berjudul "Pengaruh Model Pembelajaran Berbasis Masalah Terhadap Kemampuan Berpikir Logis Matematis Siswa SMA Negeri 1 Sekotong Pada Materi Program Linier Tahun Pelajaran 2019/2020".

\section{METODE PENELITIAN}

Jenis Penelitian ini adalah quasi eksperimen. Quasi eksperimen bertujuan untuk membandingkan kelompok yang memiliki karakteristik sama terhadap sebuah perlakuan (White \& Sabarwal, 2014). Penelitian ini menggunakan model post test-only control group. Model penelitian ini membutuhkan dua kelompok yaitu kelompok eksperimen dan kelompok kontrol yang setara. Penelitian diawali dengan memberikan perlakuan pada kedua kelompok kemudian diakhiri dengan memberikan post-test pada kedua kelompok (Campbell \& Stanley, 1963).

Tabel 2. Rancangan Penelitian

\begin{tabular}{ccc}
\hline Kelas (Kelompok) & Perlakuan & Post-test \\
\hline XI-IPA 2 (Eksperimen) & Pemb. Berbasis masalah & Ya \\
XI-IPA 1 (Kontrol) & Pemb. Langsung & Ya \\
\hline
\end{tabular}

Penelitian ini dilaksanakan sebanyak 4 pertemuan di SMA Negeri 1 Sekotong. Populasi dalam penelitian ini adalah seluruh siswa kelas XI IPA SMA Negeri 1 Sekotong tahun pelajaran 2019/2020. Pengambilan sampel dilakukan dengan teknik sampling jenuh. 
Teknik sampling jenuh yakni menjadikan seluruh anggota populasi sebagai sampel (Sugiyono, 2015).

Instrumen dalam penelitian ini berupa lembar observasi aktivitas siswa, lembar observasi aktivitas guru, dan tes kemampuan berpikir logis. Lembar observasi aktivitas guru dan siswa berfungsi untuk mengukur tingkat keterlaksanaan model pembelajaran berbasis masalah. Tes kemampuan berpikir logis terdiri dari empat soal yang mengukur tiap tiap indikator berpikir logis. Keempat indikator tersebut diantaranya adalah abstraction, generalization, judgement, dan reasoning (Atkinson, 1909).

Tabel 3. Indikator kemampuan Berpikir Logis

\begin{tabular}{|c|c|c|}
\hline No & Indikator & Keterangan \\
\hline 1 & Abstraction & $\begin{array}{l}\text { Kemampuan untuk menggambarkan atau mendeskripsikan tentang } \\
\text { suatu objek, orang, atau benda secara khusus berdasarkan ciri yang } \\
\text { hanya melekat pada objek yang digambarkan tanpa membutuhkan } \\
\text { benda atau objek tersebut. }\end{array}$ \\
\hline 2 & Generalization & $\begin{array}{l}\text { Kemampuan untuk mengelompokkan sesuatu berdasarkan gagasan } \\
\text { umum yang telah dibentuk. Pembentukan gagasan umum ini didasari } \\
\text { oleh ciri-ciri serupa yang dimiliki beberapa objek, orang, atau benda } \\
\text { tersebut. Dengan memanfaatkan keserupaan ciri-ciri yang ada maka } \\
\text { objek-objek yang ada akan disatukan dalam sebuah gagasan umum. }\end{array}$ \\
\hline 3 & Judgement & $\begin{array}{l}\text { Kemampuan dalam membandingkan dua objek, orang, atau benda satu } \\
\text { sama lain lalu menentukan hubungan antara keduanya. }\end{array}$ \\
\hline 4 & Reasoning & $\begin{array}{l}\text { Kemampuan dalam membandingkan dua objek, orang, atau benda, } \\
\text { terhadap hubungan mereka terhadap objek, orang, atau benda ketiga. }\end{array}$ \\
\hline
\end{tabular}

Validitas yang digunakan pada penelitian ini adalah validitas konstruk. Uji validitas dilakukan dengan bantuan para ahli dengan bantuan lembar validasi tes kemampuan berpikir logis (Sugiyono, 2007).

Analisis yang digunakan dalam penelitian ini adalah uji t, kemudian dilanjutkan dengan mengukur indeks effect size. Effect size digunakan untuk mengukur tingkat pengaruh model pembelajaran berbasis masalah terhadap kemampuan berpikir logis siswa (Diani, Yuberti, \& Syafitri, 2016). Penelitian ini dilakukan di lingkungan sekolah yang menyebabkan banyak siswa pada setiap kelas tidak berbeda jauh. Untuk itu, dalam penelitian ini menggunakan indeks effect size d dengan rumus sebagai berikut.

$$
d=\frac{M_{1}-M_{2}}{S D_{\text {pooled }}}
$$

$\mathrm{d}$ : indeks effect size cohen

$\mathrm{M}_{1}$ : rata-rata kelompok 1

$\mathrm{M}_{2}$ : rata-rata kelompok 2

$\mathrm{SD}_{\text {pooled: }}$ standar deviasi keseluruhan

Untuk menghitung nilai $S D_{\text {pooled }}$ pada tiap-tiap uji effect size, digunakan rumus berikut: 


$$
\begin{gathered}
S D_{\text {pooled }}=\sqrt{\frac{\sum\left(X_{1}-\bar{X}_{1}\right)^{2}+\Sigma\left(X_{2}-\bar{X}_{2}\right)^{2}}{n_{1}+n_{2}-2}} \quad \text { (Ellis, 2010) } \\
\mathrm{SD}_{\text {pooled: standar deviasi keseluruhan }} \\
\mathrm{X}_{1}: \text { nilai anggota kelompok } 1 \\
\bar{X}_{1}: \text { nilai rata-rata kelompok } 1 \\
\mathrm{X}_{2} \text { : nilai anggota kelompok } 2 \\
\bar{X}_{2}: \text { nilai rata-rata kelompok } 2 \\
\mathrm{n}_{1}: \text { banyak anggota kelompok } 1 \\
\mathrm{n}_{2}: \text { banyak anggota kelompok } 2
\end{gathered}
$$

\section{HASIL DAN PEMBAHASAN}

Penelitian dilaksanakan pada 7 Oktober sampai 16 November 2019 bertempat di SMA Negeri 1 Sekotong. Penerapan model pembelajaran berbasis masalah dilakukan pada kelas XI-IPA 2, sedangkan pada kelas XI-IPA 1 diterapkan model pembelajaran langsung sebagai pembanding. Pada setiap pertemuan, dilakukan pengamatan oleh observer untuk mengukur tingkat keterlaksanaan model pembelajaran yang diterapkan. Hasil pengamatan oleh observer akan dituliskan pada lembar observasi.

Tabel 4. Hasil Observasi Aktivitas Guru

\begin{tabular}{ccc}
\hline \multirow{2}{*}{ Pertemuan } & \multicolumn{2}{c}{ Persentase Aktivitas Guru } \\
\cline { 2 - 3 } & $\begin{array}{c}\text { Kelas Eksperimen } \\
(\mathrm{PBM})\end{array}$ & $\begin{array}{c}\text { Kelas Kontrol } \\
\text { (Langsung) }\end{array}$ \\
\hline 1 & $87 \%$ & $85 \%$ \\
2 & $87 \%$ & $88 \%$ \\
3 & $89 \%$ & $85 \%$ \\
4 & $87 \%$ & $90 \%$ \\
\hline
\end{tabular}

Pada Tabel 4 dicantumkan data hasil observasi aktivitas guru pada kelas XI IPA 1 (kontrol) dan XI IPA 2 (eksperimen). Terlihat bahwa persentase tiap keterlaksanaan tiap model pembelajaran yang diterapkan, baik itu model PBM ataupun pembelajaran langsung berada di atas $85 \%$ sehingga dikatakan bahwa pelaksanaan dua model pembelajaran tersebut sudah baik.

Tabel 5. Hasil Observasi Aktivitas Siswa

\begin{tabular}{ccc}
\hline \multirow{2}{*}{ Pertemuan } & \multicolumn{2}{c}{ Persentase Aktivitas Siswa } \\
\cline { 2 - 3 } & $\begin{array}{c}\text { Kelas Eksperimen } \\
(\mathrm{PBM})\end{array}$ & $\begin{array}{c}\text { Kelas Kontrol } \\
\text { (Langsung) }\end{array}$ \\
\hline 1 & $85 \%$ & $88 \%$ \\
2 & $91 \%$ & $85 \%$ \\
3 & $93 \%$ & $88 \%$ \\
4 & $91 \%$ & $90 \%$ \\
\hline
\end{tabular}

Pengamatan pada setiap pertemuan juga dilakukan terhadap tingkat aktivitas siswa. Terlihat bahwa tingkat aktivitas kedua kelas secara keseluruhan berada di atas $85 \%$. Jika diamati lebih lanjut, dapat dilihat bahwa pada pertemuan ke-2 kelas yang 
menggunakan model PBM memiliki aktivitas yang lebih baik daripada kelas kontrol dengan persentase di atas $90 \%$.

Setelah diterapkan model pembelajaran yang berbeda pada dua kelas tersebut, penelitian dilanjutkan dengan melakukan post test. Post test digunakan untuk mengukur tingkat kemampuan berpikir logis (KBL) siswa. Dari kegiatan post test yang dilakukan serentak terhadap kelas XI IPA-1 dan XI IPA-2 pada tanggal 16 november 2019, didapatkan data sebagai berikut.

Tabel 6. Hasil Post-Test

\begin{tabular}{cccccc}
\hline Kelas & $\begin{array}{c}\text { Banyak } \\
\text { Siswa }\end{array}$ & $\begin{array}{c}\text { Siswa yang } \\
\text { Hadir }\end{array}$ & $\begin{array}{c}\text { Rata-Rata Skor } \\
\text { Tes KBL }\end{array}$ & $\begin{array}{c}\text { Standar } \\
\text { Deviasi }\end{array}$ & Varians \\
\hline $\begin{array}{c}\text { XI-IPA 1 } \\
\text { (Kontrol) }\end{array}$ & 30 & 24 & 8,13 & 2,74 & 7,51 \\
$\begin{array}{c}\text { XI-IPA 2 } \\
\text { (eksperimen) }\end{array}$ & 30 & 27 & 11,93 & 1,98 & 3,92 \\
Jumlah & 60 & 51 & & & \\
\hline
\end{tabular}

Sebelum dilakukan analisis data, dilakukan uji prasyarat yakni uji normalitas dan homogenitas. Berdasarkan hasil uji normalitas dan homogenitas yang telah dilakukan, didapatkan bahwa dua kelas tersebut berdistribusi normal dan homogen.

Uji hipotesis pada penelitian ini menggunakan uji t pooled varians dua arah. dengan rumus sebagai berikut:

$$
t=\frac{\overline{X_{1}}-\overline{X_{2}}}{\sqrt{\frac{\left(n_{1}-n_{2}\right) s_{1}^{2}+\left(n_{2}-1\right) s_{2}^{2}}{n_{1}+n_{2}-2}\left(\frac{1}{n_{1}}+\frac{1}{n_{2}}\right)}} \quad \text { (Sugiyono, 2007) }
$$

$$
\begin{aligned}
& \mathrm{t}: \text { nilai t hitung } \\
& \overline{X_{1}}: \text { nilai rata-rata kelas eksperimen } \\
& \overline{X_{2}}: \text { nilai rata-rata kelas kontrol } \\
& \mathrm{s}_{1}: \text { standar deviasi kelas eksperimen } \\
& \mathrm{S}_{2}: \text { standar deviasi kelas kontrol } \\
& \mathrm{n}_{1}: \text { banyak siswa kelas kontrol } \\
& \mathrm{n}_{2}: \text { banyak siswa kelas kontrol }
\end{aligned}
$$

Karena uji t yang digunakan adalah uji t dua arah, maka nilai a yang digunakan harus dibagi dua. 


$\begin{array}{llr}\mathrm{H}_{0} & \text { : Tidak ada perbedaan } & \text { kemampuan } \\ & \text { berpikir logis antara } & \text { kelompok } \\ & \text { eksperimen dan kontrol } & \\ \mathrm{H}_{1} & \text { : Terdapat perbedaan } & \text { kemampuan } \\ & \text { berpikir logis antara } & \text { kelompok } \\ & \text { eksperimen dan kontrol } & \end{array}$

a $: \frac{2,5 \%}{2}=1,25 \%$

Kriteria $\quad: \mathrm{H}_{0}$ ditolak jika t hitung lebih dari $\mathrm{t}$ tabel penarikan $\quad\left(\mathrm{a}=1,25 \%\right.$ dengan $\mathrm{dk}=\mathrm{n}_{1}+\mathrm{n}_{2}-2=2,31$

kesimpulan

$$
t=\frac{11,93-8,13}{\sqrt{\frac{(27-24) 3,92+(24-1) 7,51}{49}\left(\frac{1}{27}+\frac{1}{24}\right)}}=6,90
$$

Berdasarkan data yang tertera pada Tabel 6 maka dilakukan perhitungan. Didapatkan nilai dari t hitung adalah 6,99 yang lebih besar dari nilai t tabel $(2,31)$ sehingga H0 ditolak. Sehingga dapat disimpulkan bahwa terdapat perbedaan kemampuan berpikir logis yang signifikan antara kelas eksperimen dengan kelas kontrol.

Setelah dilakukannya uji hipotesis dan disimpulkan bahwa terdapat perbedaan kemampuan berpikir logis antara kelas eksperimen dan kelas kontrol atau dengan kata lain, perlakuan yang diterapkan pada kelas eksperimen memberikan dampak terhadap kemampuan berpikir logis siswa tersebut. Selanjutnya, akan dilakukan uji effect size untuk mengetahui seberapa besar dampak atau pengaruh yang ditimbulkan dari perlakuan yang diberikan.

Berdasarkan data pada Tabel 6 maka dilakukan perhitungan dan didapatkan nilai dari $S D_{\text {pooled }}$ dan d sebagai berikut

$$
\begin{gathered}
S D_{\text {pooled }}=\sqrt{\frac{172,63+101,85}{27+24-2}}=2,37 \\
d=\frac{11,93-8,13}{2,37}=1,60
\end{gathered}
$$

Didapatkan nilai indeks effect size sebesar 1,60. Setelah hasil tersebut kita cocokkan dengan tabel effect size. Didapatkan persentase pengaruh model pembelajaran berbasis masalah terhadap kemampuan berpikir logis sebesar 94,5\% dengan kategori besar.

Berdasarkan data yang tertera pada hasil observasi, didapatkan bahwa total banyak siswa pada kelas XI IPA adalah 60 orang siswa yang terbagi menjadi 30 siswa kelas XI IPA 1 dan 30 siswa kelas XI IPA 2. Sehingga asumsi awal untuk statistik uji yang 
digunakan adalah statistik uji untuk banyak anggota yang sama pada kelompok kontrol dan kelompok eksperimen.

Dalam kegiatan post-test didapatkan hasil yang berada di luar dugaan. Yaitu terdapat beberapa siswa yang tidak hadir saat dilakukannya post-test sehingga membuat data yang didapatkan tidak sesuai dengan asumsi awal. Untuk itu, dalam analisis akan dilakukan penyesuaian terhadap banyak data yang didapatkan baik untuk kelas XI IPA 1 selaku kelompok kontrol dengan data yang terkumpul sebanyak 24 dan kelas XI IPA 2 selaku kelompok eksperimen dengan data yang terkumpul sebanyak 27 .

Berdasarkan dua uji prasyarat yang telah dilakukan, didapatkan bahwa data berdistribusi normal dan memiliki varians yang homogen, untuk itu digunakan uji-t pooled varians sebagai uji hipotesis. Setelah melakukan uji-t didapatkan bahwa memang terdapat perbedaan hasil antara kemampuan berpikir logis kelas eksperimen dengan kemampuan berpikir logis kelas kontrol. Itu berarti memang terdapat pengaruh dari model pembelajaran berbasis masalah yang diterapkan pada kelas eksperimen terhadap kemampuan berpikir logis siswa di SMA Negeri 1 Sekotong.

Dalam mengukur besar pengaruh model pembelajaran berbasis masalah terhadap kemampuan berpikir logis siswa, digunakan uji effect size yang dilakukan dengan membagi selisih dari skor rata-rata kelas eksperimen dan kelas kontrol dengan standar deviasi. Dari perhitungan tersebut didapatkan nilai indeks effect size sebesar 1,60. Nilai tersebut memiliki makna bahwa pengaruh model pembelajaran berbasis masalah yang diterapkan pada kelas XI-IPA 2 terhadap kemampuan berpikir logis siswa di kelas tersebut adalah sebesar 94,5\% yang dimasukkan dalam kategori besar.

Hal ini sejalan dengan hasil penelitian Rohaeti yang mengungkapkan bahwa model pembelajaran berbasis masalah dapat meningkatkan kemampuan berpikir logis. Rohaeti mengungkapkan sebelum diterapkan model pembelajaran berbasis masalah, siswa memiliki kemampuan berpikir logis yang rendah. Kemampuan tersebut meningkat seiring dengan diterapkannya pembelajaran berbasis masalah (Rohaeti et al., 2014). Meskipun begitu, menurut Nugraha dan Mahmud model pembelajaran berbasis masalah dinilai kurang efektif jika ditinjau dari kemampuan berpikir logis. meskipun begitu, pembelajaran ini masih lebih baik dibandingkan dengan pembelajaran konvensional (Nugraha \& Mahmud, 2015).

Untuk mendapatkan bukti pendukung, peneliti mencoba membandingkan jawaban dari siswa pada kelas eksperimen dan kelas kontrol. Peneliti membandingkan perbedaan masing-masing kelas dalam hal jawaban dan cara menjawab. 
Tabel 7. Rata-Rata Skor Lembar Kerja Siswa Kelas XI-IPA 1 (Kontrol)

\begin{tabular}{ccccc}
\hline \multirow{2}{*}{ Indikator } & \multicolumn{4}{c}{ Rata-rata } \\
\cline { 2 - 5 } & LK1 & LK2 & LK3 & LK4 \\
\hline Abstraction & 1,7 & 1,8 & 1,8 & 2,0 \\
Generalization & 1,2 & 1,8 & 1,7 & 1,7 \\
Judgement & 1,0 & 1,5 & 1,3 & 1,0 \\
Reasoning & 1,0 & 0,7 & 1,2 & 0,3 \\
\hline
\end{tabular}

Tabel 8. Rata-Rata Skor Lembar Kerja Siswa Kelas XI-IPA 2 (Eksperimen)

\begin{tabular}{ccccc}
\hline \multirow{2}{*}{ Indikator } & \multicolumn{4}{c}{ Rata-rata } \\
\cline { 2 - 5 } & LK1 & LK2 & LK3 & LK4 \\
\hline Abstraction & 1,8 & 1,8 & 1,8 & 2,0 \\
Generalization & 1,5 & 1,8 & 1,7 & 2,0 \\
Judgement & 0,8 & 1,3 & 1,5 & 1,7 \\
Reasoning & 1,0 & 0,7 & 1,5 & 1,0 \\
\hline
\end{tabular}

Berdasarkan tabel 7 dan tabel 8 dapat terlihat secara jelas perkembangan kemampuan berpikir logis antara kelas eksperimen dan kelas kontrol. Pada indikator abstraction (abstraksi), dari dua kelas, tidak ada perbedaan yang terlalu berarti. Kedua kelas baik kelas eksperimen ataupun kelas kontrol telah memiliki kemampuan abstraksi yang setara.

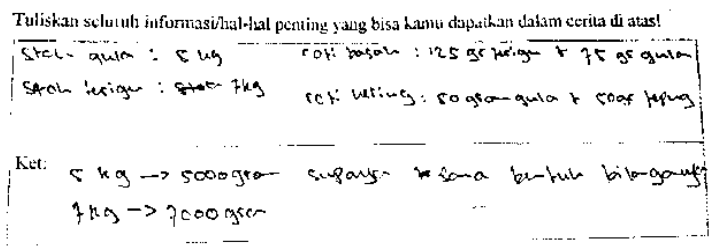

(a) Kelas Eksperimen

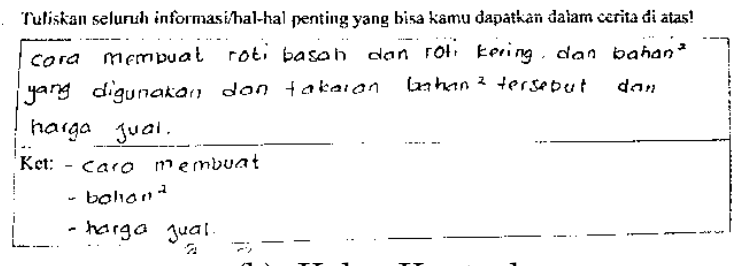

(b) Kelas Kontrol

Gambar 1. Jawaban Siswa 1

Pada soal pertama post-test, terdapat perbedaan jawaban antara kelas kontrol dan eksperimen. Sebagian besar siswa kelas eksperimen telah mampu menyaring dan memilih informasi penting yang dibutuhkan untuk menyelesaikan masalah. Selain itu, pada kolom keterangan dilakukan pengubahan satuan agar mempermudah proses berikutnya. Pada kelas kontrol, sebagian besar siswa menuliskan jawaban secara garis besar dan tidak mendetail. Keterangan yang diberikan kurang sesuai dengan jawaban. Pada gambar 1 menunjukkan bahwa kemampuan abstraksi kelas eksperimen lebih tinggi. Siswa pada kelas eksperimen telah mampu mendeskripsikan dua jenis roti yang berbeda berdasarkan bahan yang digunakan.

Secara berkelompok, perkembangan kemampuan abstraksi dua kelas tersebut sama, namun ketika dilakukan pengukuran secara individu terlihat perbedaan yang cukup jelas. Pada gambar 1 menunjukkan bahwa kemampuan abstraksi kelas eksperimen lebih tinggi. Siswa pada kelas eksperimen telah mampu mendeskripsikan dua jenis roti yang berbeda berdasarkan bahan yang digunakan. 
Dalam indikator generalization (generalisasi) yang tertuang pada jawaban nomor dua. Jawaban dari kedua kelas terlihat sama. Kedua kelas telah memiliki kemampuan generalisasi. Mereka telah mampu mengelompokkan variable roti basah (x) dan roti kering (y) kemudian membentuknya menjadi kalimat matematika. Perbedaan terlihat pada bagian keterangan. Kelas eksperimen telah mampu menjelaskan alasan dari jawaban yang mereka tulis. Sedangkan kelas kontrol terkesan hanya menuliskan ulang jawaban di atasnya.

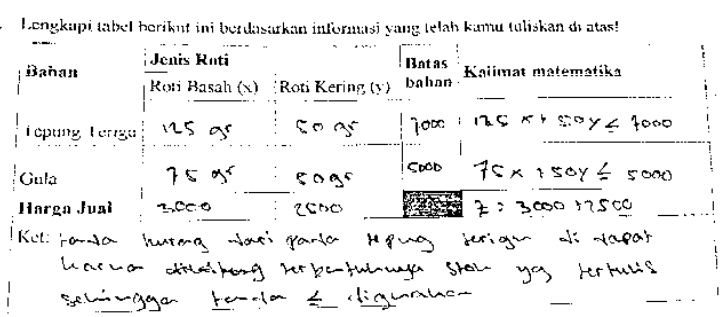

(a) Kelas Eksperimen

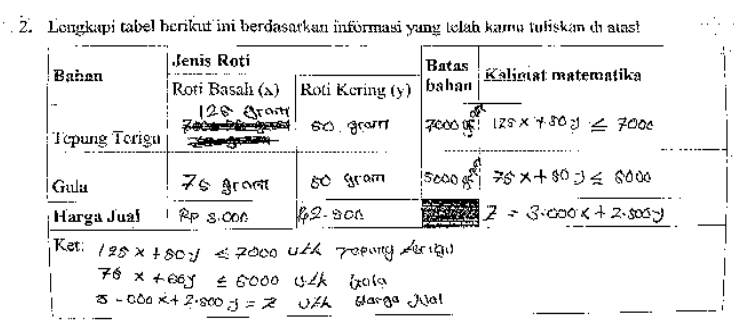

(b) Kelas Kontrol

Gambar 2. Jawaban Siswa 2

Pada indikator judgement yang tertuang di soal nomor tiga, kedua kelas mengalami kesulitan dalam menjawabnya. Kesulitan terjadi pada bagian keterangan. Sebagian besar siswa kelas eksperimen telah menjawab dengan baik namun terlalu terpaku pada rumus. Hal tersebut menyebabkan kolom keterangan yang disediakan masih kurang sehingga siswa menuliskan rumus pada halaman belakang kertas. Sedangkan siswa kelas kontrol cenderung mengisi kolom keterangan dengan jawaban yang kurang sesuai.

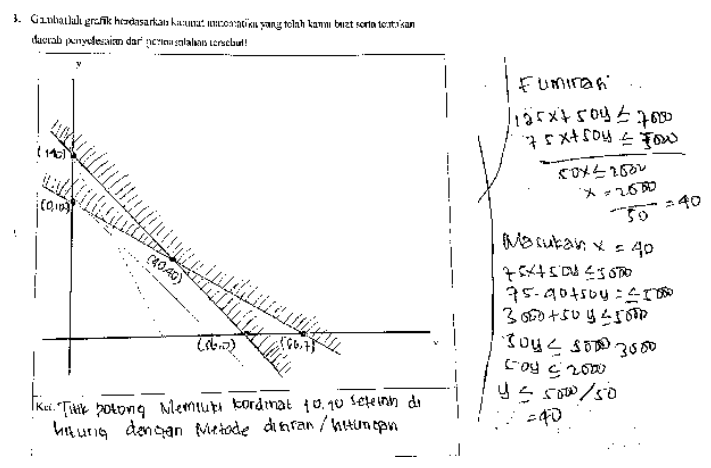

(a) Kelas Eksperimen

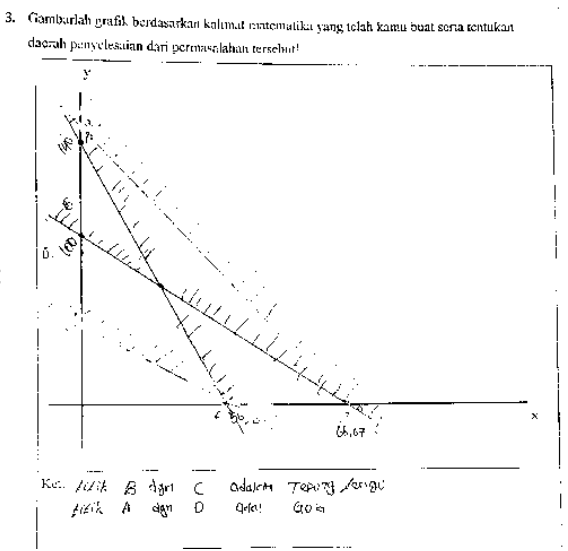

(b) Kelas Kontrol

Gambar 3. Jawaban Siswa 3

Keterangan yang diharapkan dalam soal nomor tiga sebenarnya sederhana. Diharapkan siswa menuliskan alasan daerah dalam grafik menjadi daerah penyelesaian, atau alasan yang menyebabkan arah arsiran ke atas atau ke bawah. Namun karena terlalu terpaku 
dengan rumus, dan terlalu terpaku dengan metode sebelumnya yakni metode titik uji, kolom keterangan yang disediakan tidak cukup untuk menuliskan penjelasan.

Pada indikator reasoning yang tertuang di soal terakhir, hampir tak ada siswa yang meraih skor maksimal. Soal keempat ini menguji kemampuan bernalar siswa. Siswa diharapkan mampu menghubungkan informasi yang terkumpul pada soal pertama, dibentuk menjadi kalimat matematika pada soal kedua, dan digambarkan dalam bentuk grafik pada soal ketiga. Setelah itu, siswa diharapkan dapat menentukan penyelesaian dari soal cerita yang diberikan dengan membandingkan beberapa alternatif jawaban yang didapatkan dengan mengamati grafik pada soal nomor tiga.

Dalam menentukan hasil akhir, siswa kelas eksperimen tidak mengalami kesulitan yang berarti. Kesulitan utama yang dialami oleh kelas eksperimen adalah dalam memberikan keterangan. Sebagian besar siswa kelas eksperimen memberikan keterangan yang kurang sesuai dengan jawaban. Sedangkan pada kelas kontrol, kebanyakan siswa justru tidak mengisi kolom keterangan.

Berdasarkan pembahasan di atas, telah terlihat bahwa dari empat indikator yang ada, keseluruhannya mengalami peningkatan kecuali indikator pertama abstraction yang sudah berada pada skor maksimal sejak pertemuan pertama. Untuk indikator lainnya, yaitu, generalization, judgement, dan reasoning terbukti telah mengalami peningkatan berkat penerapan model pembelajaran berbasis masalah.

Setelah melihat jawaban post-test dengan seksama, proses berpikir logis sebenarnya telah terjadi dalam setiap siswa. Hal ini dibuktikan dengan jawaban siswa yang telah sesuai dengan harapan. Namun sebagian siswa masih belum memahami alur keseluruhan dalam proses berpikir yang mereka lalui. Siswa hanya terpaku kepada rumus dan hasil akhir, tanpa mencoba untuk memahami alur yang dibutuhkan untuk mencapai hasil akhir tersebut. Ini terbukti dari beberapa jawaban yang tidak dilengkapi dengan keterangan yang sesuai.

Jadi, berdasarkan perkembangan kedua kelas pada tiap pertemuan serta pengamatan pada jawaban yang diberikan siswa pada tiap kelas, didapatkan bahwa penerapan pembelajaran berbasis masalah terbukti mampu meningkatkan kemampuan berpikir logis pada siswa Kelas XI-IPA SMA Negeri 1 Sekotong tahun pelajaran 2019/2020.

\section{SIMPULAN}

Bagian ini memaparkan simpulan penelitian sesuai dengan hasil dan temuan penelitian. Bagian ini tidak perlu ada kutipan atas simpulan. Kesimpulan menggambarkan jawaban atas hipotesis dan / atau tujuan penelitian atau temuan ilmiah yang diperoleh. Kesimpulan tidak mengandung pengulangan hasil dan diskusi, melainkan merangkum temuan seperti yang diharapkan dalam tujuan atau hipotesis. 
Berdasarkan hasil penelitian, analisis data, dan pembahasan, dapat diambil kesimpulan sebagai berikut:

1. Terdapat pengaruh/kontribusi yang signifikan dari model pembelajaran berbasis masalah terhadap kemampuan berpikir logis matematis siswa kelas XI-IPA di SMA Negeri 1 Sekotong.

2. Pengaruh/kontribusi model pembelajaran berbasis masalah terhadap kemampuan berpikir logis siswa kelas XI-IPA di SMA Negeri 1 Sekotong sebesar 94,5\%.

Untuk melakukan penelitian serupa, disarankan bagi para pembaca untuk lebih memperhatikan kualitas pelaksanaan dari model pembelajaran yang digunakan dan membandingkan dengan kualitas dari model pembelajaran lainnya yang digunakan sebagai pembanding. Selain itu, dalam penerapan model pembelajaran berbasis masalah, alangkah baiknya jika guru dituntut aktif membimbing siswa agar kegiatan diskusi dalam tahap penyelidikan individu/kelompok dapat berjalan dengan maksimal.

\section{REFERENSI}

As'ari, Abdur, R., Tohir, M., \& Valentino, E. (2017). Buku Guru Matematika SMP/MTs Kelas VIII. Jakarta: Kemendikbud.

Atkinson, W. W. (1909). The Art of Logical Thinking: The Laws Of Reasoning. Hollister: Yogeebooks.

Campbell, D. T., \& Stanley, J. C. (1963). Experimental and Quasi-Experimental Designs for Research. Boston: Houghton Mifflin Company.

Diani, R., Yuberti, \& Syafitri, S. (2016). Uji effect size model pembelajaran scramble dengan media video terhadap hasil belajar fisika peserta didik kelas X MAN 1 pesisir barat. Jurnal Ilmiah Pendidikan Fisika Al-BiRuNi (Vol. 2(5), pp. 267-277).

Ellis, P. D. (2010). The Essential Guide to Effect Sizes. New York: Cambridge University Press.

Hasratuddin. (2014). Pembelajaran matematika sekarang dan yang akan datang berbasis karakter. Jurnal Didaktik Matematika (Vol. 1(2), pp. 30-42).

Jufri, A. W. (2013). Belajar dan Pembelajaran Sains. Bandung: Pustaka Reka Cipta.

Jurkovic, V., Sarlota, G., Vukadinovic, N., \& Jarc, M. (2005). Guide to Problem-Based Learning. Ljubljana: Slovene Association of LSP Teachers.

Menteri Pendidikan Dan Kebudayaan. (2016). Peraturan Menteri Pendidikan Dan Kebudayaan Nomor 22 Tahun 2016. Jakarta: Kemendikbud.

Nugraha, T. S., \& Mahmud, A. (2015). Keefektifan pembelajaran berbasis masalah dan problem posing ditinjau dari kemampuan berpikir logis dan kritis. Jurnal Riset Pendidikan Matematika (Vol. 2(1), pp. 107-120).

Nurdyansyah. (2016). Inovasi Model Pembelajaran. Sidoarjo: Nizamia Learning Center.

Nursupianah, I., \& Fitriyah, R. A. (2012). Hubungan pola berpikir logis dengan hasil belajar matematika siswa. EduMa: Mathematics Education Learning and Teaching (Vol. 1(2), pp. 14-24).

Rohaeti, E. E., Budiyanto, \& Sumarmo, U. (2014). Enhancing student's mathematical logical thinking ability and self-regulated learning through problem based learning. International Journal of Education (Vol. 8(1), pp. 54-63). 
Siswono, T. Y. E. (2007). Meningkatkan kemampuan berpikir kreatif siswa melalui pengajuan masalah dan pemecahan masalah matematika. Makalah: disampaikan pada Simposium Nasional Penelitian Pendidikan, Pusat Studi Kebijakan Departemen Pendidikan Nasional. Jakarta: 25-26 Juli. Simposium Nasional Penelitian Pendidikan, Pusat Studi Kebijakan Departemen Pendidikan Nasional.

Suaedi. (2016). Pengantar Filsafat Ilmu. Bogor: IPB Press.

Sugiyono. (2007). Statistika Untuk Penelitian. Bandung: Alfabeta.

Sugiyono. (2015). Metode Penelitian Pendidikan (Pendekatan Kuantitatif, Kualitatif, dan R\&D). Bandung: Alfabeta.

White, H., \& Sabarwal, S. (2014). Quasi-experimental Design and Methods, Methodological Briefs: Impact Evaluation 8. Florence: UNICEF Office of Research.

Wood, D. F. (2003). Problem based learning. ABC of Learning and Teaching in Medicine (Vol. 326(7384), pp. 328-330).

Zulfairanatama, G., \& Hadi, S. (2013). Kecerdasan logika-matematika berdasarkan multiple intelligences terhadap kemampuan matematika siswa SMP di banjarmasin. Jurnal Pendidikan Matematika (Vol. 1(1), pp. 18-26). 